\title{
Are Early Period Maladaptive Schemas Effective in Adolescence? Their Effect on Parenting Styles and the Need for Social Approval
}

\author{
Halil Ekşi ${ }^{1}$, Nesrullah Okan ${ }^{1, *} \&$ Serra Dinç ${ }^{2}$ \\ ${ }^{1}$ Marmara Unversity, Istanbul, Turkey \\ ${ }^{2}$ Sağlık Bilimleri Üniversitesi, Istanbul, Turkey \\ *Correspondence: Marmara University, Istanbul, Turkey. E-mail: nesrokan@gmail.com \\ Received: September 12, 2020 \\ Accepted: November 18, 2020 Online Published: December 20, 2020 \\ doi:10.5430/wje.v10n6p123 \\ URL: https://doi.org/10.5430/wje.v10n6p123
}

\begin{abstract}
The aim of this study is to examine the mediating effect of early maladaptive schemas in the relationship between parenting style and the need social approval. In this study, scales were applied to 379 university students and analyzes were conducted in line with their answers. As a result of the final analysis, it was concluded that the high standard scheme had an intermediary role effect between parenting style and the need social approval.Positive studies on early childhood schemes in psychotherapy can help people to solve their problems.
\end{abstract}

Keywords: parenting style, social approval need, schemas

\section{Introduction}

The concept of schema can define as the perception and perspective developed by the person about life that is the fundamental mental structures. These structures begin to take shape in childhood and continue to grow as life progresses. This process, which takes place in a way that is unique to each person, interprets all situations and experiences encountered and affect different behaviors (Beck, 2008; Young, Klosko \& Weishaar, 2017). As a result of the failure to meet the emotional needs of the people in their early life, their mental structures, which affect them and their relationships, also form early maladaptive schemas. (Young, 1999; cited in Sarıtaş and Gençöz, 2013; Young, Klosko and Weishaar, 2017). Early maladaptive schemas usually occur outside the awareness of the individual. Thus cause many psychological problems such as eating disorder, depression, obsessive-compulsive disorder, personality disorders, and narcissism. (Cullum, 2009; Demir and Kaya, 2016; Harris and Curtin, 2002; Sarıtaş and Gençöz, 2013; Roelofs, Lee, Rujiten ve Lobbestael, 2011; Thimm, 2010; Zeigler-Hill, Green, Arnau, Sisemore ve Myers, 2010).

Early maladaptive schemas have five schema domains and 18 sub-dimensions in total. These schema domains are areas of disconnection and rejection, impaired autonomy and performance, reduced limits, other-directedness, over vigilance and inhibition. The self-sacrifice scheme, which is the subject of the research is in the domain of other-directedness. For the people with schemes in this domain, others come before their own needs. The basis of that is their avoidance of adverse reactions by other individuals and their need for approval. Different schemas of this domain are obedience and support. The high standards scheme, which is another variable of the study is in the area of over vigilance and inhibition. Individuals with a high standards scheme are those who are not content with what they have and are continually setting new goals. They always feel under pressure to succeed. People with schemas in this domain often try to obey the rules in their childhood experiences in situations such as communication and self-expression and repress their feelings. Because they look for perfection, which they think would never be reachable. They believe that their lives will turn upside down when they cannot reach this. Other schemas of this domain are pessimism, punitiveness, and emotionally inhibition (Young, Klosko and Weishaar, 2017).

The child's relationship with the parent or the child's perception towards the parent's attitudes gives shape to a child's understanding of the world in other words to the schemas. When maladaptive schemas occur in adulthood, actually the scenes from relationships with parents in childhood occur (Young, Klosko and Weishaar, 2017). Briefly, parenting styles can be seen as the basis of early maladaptive schemas (Murris, 2006; Soygüt \& Cakir, 2009). Studies 
are done about that also confirm the relationship between parenting styles and first maladaptive schemes (Kapçı \& Hamamc1, 2010; Soygüt \& Çakır, 2009; Terri, Messman-Moore \& Coates, 2007; Yurtsever \& Sütçü, 2017).

In Young's theory of parenting styles, the parental dimensions are; normative, belittling/criticizing, emotional deprivation, mistrust/abuse, overprotective/anxious, conditional/achievement-focused, over permissive/boundless, pessimistic/worried, punitive and restricted/emotionally inhibited. Parenting styles, which are the subject of this research, are; normative, overprotective/anxious, and belittling/criticizing and conditional/achievement-focused. In prescriptive parenting style, there are wishes and thoughts such as asking the things to be done quickly and adequately, behaving perfectionist and demanding, having everything under their control, focusing the child to be more adequate, feeling that it is not enough, being angry when something done is wrong and keeping the expectations high . In belittling/criticizing parenting style, parent treats the children as if they always behave in a wrong way, they are incompetent and unworthy of love, make them believe that their ideas are insignificant, convinces them that they would fail, and causes them to be ashamed of themselves. In overprotective/anxious parenting style, there are overprotective behaviors that do not allow the children to stand on their foot and causes them not to trust themselves. In conditional/achievement-focused parenting, there are behaviors such as being overly concerned with what the other people think about the things the child does, always expecting the best from the child and showing more compassion when the child is successful (Soygüt, Çakır and Karaosmanoğlu, 2008).

In the development of schemas, there are some factors such as communication with the environment, social life, school. However, none of them is as effective as the relationship with parents. The negative attitudes of the parents develop negative schemas such as not being able to belong to somewhere, not being able to express emotions and maybe hurt by others (Kömürcü and Soygüt Pekak, 2016). Primarily when it is evaluated based on the parenting styles children who are restricted by their parents to express their emotions, tend to care to meet the needs of others and to get approval. In these people, the schemas of self-sacrifice, submission, and support develop. Likewise, children with normative parents follow the rules by suppressing their feelings and thoughts. In these children, schemas such as high standards and punitive have come along in their adulthood (McCarthy and Lumley, 2012; Young, Klosko and Weishaar, 2017). The children of parents who have overprotective attitudes also have directedness to others, approval, submission, and high standards schemas (McGinn, Cukor and Sanderson, 2005; Turner, Rose, and Cooper, 2005). In the study of Çolakoğlu (2012) overprotective, conditional / achievement-focused mother and normative father attitudes affected the other-directedness schema field. Again, in the same study, it was observed that overprotective mother and normative and belittling father attitudes changed the over vigilance schema field. In their studies, Sheffield, Waller, Emanuelli, Murray, and Meyer (2005) it was found a relationship between the other-directedness schema field and the conditional/achievement-focused parent. Also, there is a relationship between the over vigilance schema field and normative and conditional/achievement-focused attitudes of mother and father.

The other variable of the study, the concept of social approval, is defined as the desire to get permission from others, and avoidance of not to get approval (Leite and Beretvas, 2005). Social acceptance and to establish relationship are also seen as the needs of the person (Erözkan, 2004). Individuals with a high demand for approval are inclined to behave in a way that they would get support from others. These people's approval by others and seeing positive returns as a need also reveals their feelings of anxiety. People with social concerns attach great importance to other people's thoughts and worries about how others evaluate them. Based on social anxiety, there is a fear of not being approved (Thomas, 2000). Current studies have found a high level of relationship between social anxiety and fear of disapproval and criticism. (Leary and Kowalski, 1995; cited in, Sertelin Mercan and Yavuzer, 2017; Rapee and Heimberg, 1997; mentioned in Erkan, 2002; Karasar, 2014; Twenge and I am, 2007; Young, Klosko and Weishaar, 2017). This situation shows us that the need for social approval and social anxiety meet on common ground.

The other features that people in need of social approval meet on the common ground are the behaviors like the efforts to satisfy others, being compatible, perfectionism, and sacrifice (Karaşar, 2014). Thus suggests that there is a relationship between the other-directedness field which is one of the early maladaptive schemas and contains sacrifice, submission and approval search and over vigilance which includes high standards, pessimism, punitive and emotionally inhibition and with the schemas in inhibition fields and needs for social support. Ceylan(2011) in his research, has found a relationship between the search for approval schema from the other-directedness area and social anxiety, which also suggests that there is a relationship between the need for social support and other schemes of this field. For example, a need for social approval can occur for people with a self-sacrifice schema. Because just like the self-sacrifice schema is described as a self-sacrifice scheme that the people give serious importance to the wishes and desires of others, put their preferences into the background (Young, Klosko and Weishaar, 2017). 
Individuals with a high need for social approval can comply with expectations and create high standards for themselves. According to the definition of Jansson-Fröjmark and Linton (2007), perfectionism is related to the need for social approval if one considers that perfectionism means a person's high expectations towards him/her and feels anxiety when it is not. In a study of Sherry (2002) with 211 young adults, 70 inpatient and outpatient psychiatric patients, it was revealed that psychiatric patients predicted self-directed perfectionism and the need for the approval of perfectionism determined by others. He found that also for young adults, the perfectionism determined by others predicted the need for social support. Studies are showing that there is a high level of relationship between perfectionism and social anxiety including fear of not being approved as well (Cox and Chen, 2015; Scott, Yap, Francis and Schuster, 2014; Karakas, 2008). Thus, shows the relationship between the high standards schema and the need for social approval.

When the studies on the relationship between parenting styles and different general psychological problems assessed, results are found to be related (Azar, Nix and Makin-Byrd, 2005; Basile and Mancini, 2015; Çolakoğlu, 2012; Türk, Duy, Hamamcı and Altınok, 2017). According to Burns (2016), people who have a high need for social approval may turn to this as a result of their relationship with their parents. Considering the studies stated that there is a relationship between parenting styles and approval search schema above, these results include the relationship between the need for social approval and the parenting styles. Similarly, when the need for social approval reevaluated as a sign of perfectionism and social anxiety, the relationship between parenting styles and perfectionism and social anxiety also suggests this relationship with the need for social approval.

In this respect, people who exposed to success-oriented parenting may also need high social approval. For example, conditional / success-oriented perfectionist parents approve their children when their performance is high, and they do not accept the situations when their performances are low. Accordingly, children also become perfectionists who do not want to make mistakes to get their parents' approval, in other words, they need high approval (Burns, 1980; cited in Karaşar, 2014). According to the research conducted by Ablard and Parker (1997), the children of success-oriented parents show a higher level of non-functional perfectionism than the children of learning-oriented parents.

Overprotected/anxious parents also have behaviors such as overprotection that will not allow their children to do anything by themselves and cause their self-esteem to fall (Soygüt, Çakır, \& Karaosmanoğlu, 2008). There are also studies showing that there is a high desire to be approved in individuals who exposed to over-protective parental attitudes (Erkan, Güçray, and Çam, 2002; Pekşen Akça, 2012). Considering the studies that show that overprotective, authoritarian and normative parenting attitudes lead to social anxiety, it can be thought that these parenting styles are also related to the need for social approval (Çağdaş and Secer, 2004; Dökmen, 1996; Erözkan, 2007; Erözkan, 2012; Sübaş1, 2007; Yavuzer, 2005).

The normative parents have behaviors such as expecting their children always to be better, reacting to them when they behave differently than their parents' wishes and keeping expectations high. As a consequence, behaviors occur in children such as the need for not receiving adverse reactions from the family and the need for approval (Soygüt, Çakır and Karaosmanoğlu, 2008). Baumrind's (1980) attitude of parenting defined as authoritarian is an attitude that sets high standards for children and educates them under strict discipline (Akt., Sümer, Aktürk, \& Helvac1, 2010, p.43). The definition of authoritarian parenting appears to be the same as the normative parenting (Soygüt, Cakir, \& Karaosmanoglu, 2008). According to Sümer, Aktürk, and Helvacı (2010), individuals with authoritarian parenting attitude are those who have high-level anxiety and seek approval in their relationships. Therefore, the normative style of parenting will lead to this conclusion.

Insufficiency thoughts occur in children who raised in belittling and criticizing ways and, if this continues in adulthood, they can avoid many close relationships with concern for rejection and develop many mental problems (Sheffield et al., 2005; Harris and Curtin, 2002). In the study conducted by Eldoğan and Tuncel (2017), a relationship observed between normative, the belittling/criticizing, the overprotective/anxious mother and father parental styles in the individuals with high social anxiety. Thus, suggests that there is also a relationship between the need for social approval from the symptoms of social concern and success-oriented /belittling, normative, over-protective /anxious belittling/criticizing parenting styles.

The studies mentioned above consider that it has seen that studies are explaining the relationship between parenting styles and early incompatible schemas in the literature. However, there is a limited number of studies on the relationship between the need for social approval and parenting styles. The relationships between the variables such as social anxiety and perfectionism, which are a sub-dimension of early period incompatible schemas, the relationship between approval search and parenting styles and the need for social approval, and the relationships 
between all early age incompatible schemas and all parenting styles examined. Based on the results of the studies described above, parenting styles and early period incompatible schemas that may be associated with the need for social approval evaluated for this study. For this reason, the purpose of the research you are reading is to examine the mediator role of high standards and self-sacrifice schemas in the relationship between normative, belittling/criticizing, overprotective/anxious and conditional/achievement-focused parenting styles, and the need for social approval.

\section{Method}

\subsection{Research Model}

This research is a relational model designed to examine the relationships between the various variables and to test the direct and indirect effects between these variables. SEM (Structural Equation Model) was used to achieve this goal.

\subsection{Population and Sample}

In this research, because of the difficulty of reaching the general population, the study population was used. Accordingly, the study population of the study consisted of 5641 students attending undergraduate programs at Atatürk Education Faculty of Marmara University during the spring term of 2017-2018 academic years. While the sample size of the study was determined, the sample size calculated as $n=360$ with $95 \%$ confidence interval and $\pm 5 \%$ sampling error for the non-homogeneous population (Salant and Dillman, 1994). The number of sufficient samples was determined as 390 persons to increase the representation rate of the sample considering possible data losses. The sample group of the study consisted of the students who study at Atatürk Faculty of Education, which were chosen randomly from the sections constituting the study population by the proportional cluster sampling method.

\section{Demograpichic Information Of Students}

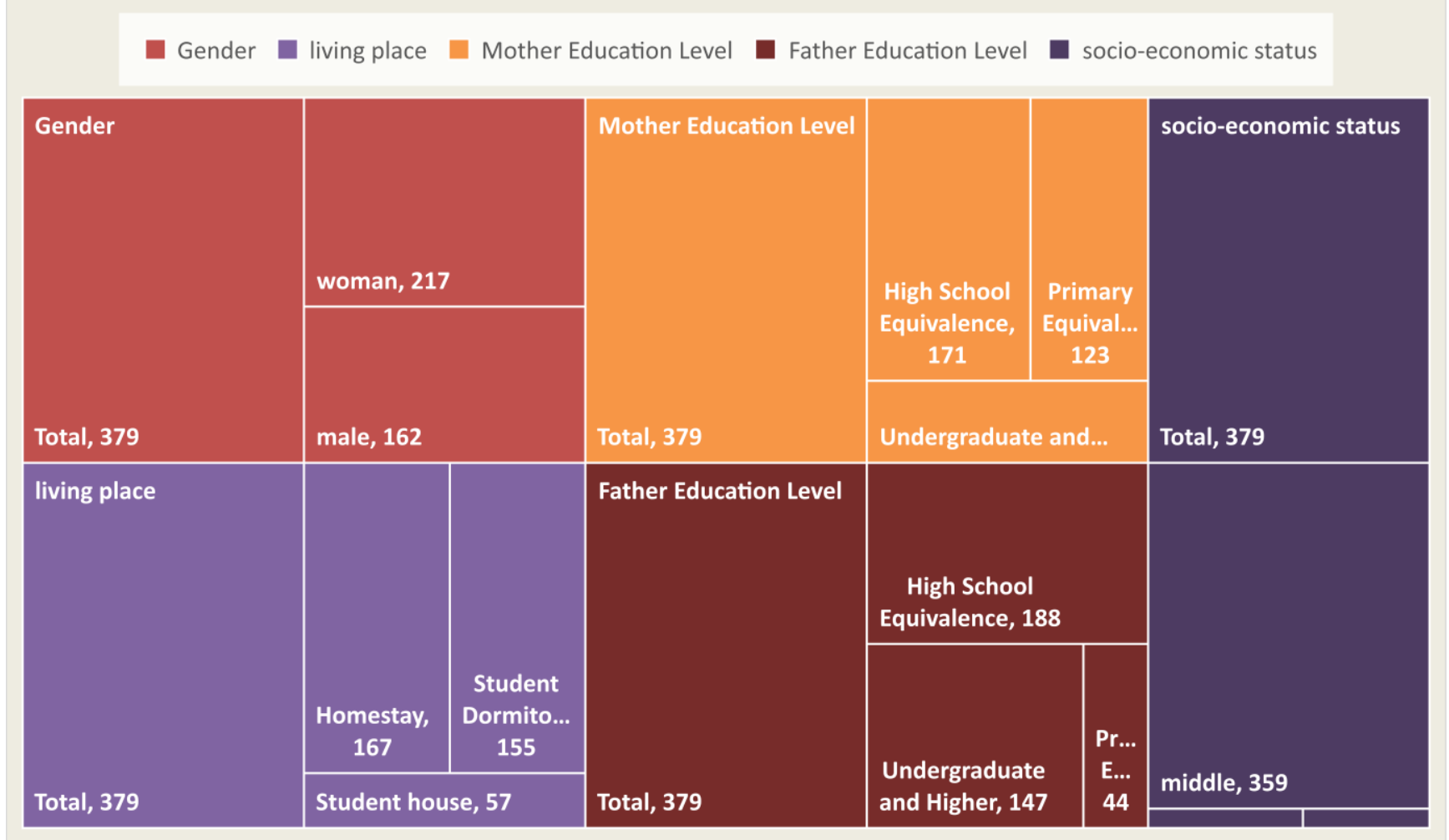

Graphic 1. Demographic Information of Students Participating in the Research

390 people participated in the research, after the ones whom uncompleted the scales eliminated; there remained a total of 379 people, $217(57.3 \%)$ women, and $162(42.7 \%)$ men. Of the participants, 167 (44.1\%) were staying with families, 155 (40.9) in dormitories, and $57(15.0 \%)$ at their student home. The mothers of 123 participants(32.5\%) 
were elementary education graduates, mothers of 171 participants $(45.1 \%)$ were high school, or equivalents graduates and mothers of 85 participants $(22.4 \%)$ were bachelor's or master's degrees graduates. When the father education status of the participants examined, it has seen that 44 (11.6\%) father's primary school graduates, $188(49.6 \%)$ fathers are high school graduates and $147(38.8 \%)$ fathers are graduates of undergraduate or graduate school.

\subsection{Data Collection Tools}

Social Approval Need Scale: The scale developed by Karaşar and Öğülmüş (2016) to measure the need for social approval is 5-point Likert type and measures three sub-dimensions (sensitivity to the judgment of others, positive impression and social withdrawal) related to the need for social approval. The scale consists of 25 items. The high scores on the Social Approval Need Scale suggest that the need for social approval has increased. The topics related to the scale scored between "I totally agree" and "I strongly disagree". The internal consistency coefficients about the subscales of the Social Approval Need Scale found between .80 and .83 . The internal consistency coefficient for the whole scale was .90 .

Young Parenting Inventory: To evaluate the various behaviors of the parents, which form the basis of early incompatible schemas, Soygüt, Çakır, and Karaosmanoğlu (2008) adapted from the Young Parenthood Scale to Turkish. The original developed by Young (1994), and the reliability validated by Sheffield et al. (2006). The original form has 17 sub-dimensions. The Turkish form is a 6-point Likert type and consists of 72 items and ten sub-dimensions (normative, belittling/criticizing, emotional deprivation, mistrust/abuse, overprotective/anxious, conditional/achievement-focused, over permissive/boundless, pessimistic/worried, punitive, and restricted/emotionally inhibited). In this study, 33 items of four sub-dimensions used, which are normative, belittling/criticizing, overprotective/anxious, and conditional/achievement-focused. The topics related to the scale are scored between 'completely wrong' and 'completely matches.' The internal consistency coefficients of the scale range from alpha $=.53$ to .86 in the form of mother, and alpha $=.61-.89$ in the way of father. Young

Young Schema Questionnaire-Short form -3: It was developed by Young (2003) to identify early incompatible schemas, and in the original form of the scale there are 18 sub-dimensions under five schema space. These schema domains are disconnection and rejection, impaired autonomy and performance, reduced limits, other-directedness, over vigilance, and inhibition. It consists of 90-items and a 6-points Likert type and scored between 'it is completely wrong for me' and 'it perfectly defines me.' High scores on the scale indicate how much the person's level of functionality is affected. The scale was adapted to Turkish by Soygut, Karaosmanoglu, and Cakir (2009). The principal component analysis of the construct validity shows the 14-factor structure. These factors are Emotional Deprivation, Failure, Pessimism, Social Isolation / Insecurity, Emotion Suppression, Approval Seeking, Intertwinement/ Codependency, Privilege / Inadequate Self-Control, Self-Sacrifice, Be Abandonment, Punishing, Imperfection, Weakness against Diseases and Damage, and High Standards. The internal consistency coefficient of the scale was found to be $\alpha=.95$ according to the validity study. The internal consistency coefficients of the subscales were found to be between .54 and .85 and were found to be sufficiently valid and reliable. In this research, the Self Sacrifice schema $(\alpha=.74)$ used from the domain of, and High Standards schemas $(\alpha=.53)$ used from the domain of Over vigilance and inhibition.

\subsection{Data Analysis}

In this study, it is aimed to investigate the mediating role effects of sacrifice and high standards schemes in the relationship between the needs of parenting and social approval needs of the students of Atatürk Education Faculty. After the necessary permissions obtained from the owners of the scale, data were collected., the Pearson Product Moment Correlation analysis performed to analyze the data with the help of the SPPS 22 package program, and then the AMOS 20 package program was used to test the structural equation model. Path analysis is a collection of statistical techniques that allow the testing of predictive causal and unidirectional relationship sequences (Tabachnick and Fidell, 2015).

\section{Findings}

Before moving on to actual analyses that constitute the primary hypothesis of the research, prerequisite analyses conducted for the reliability of the study. In this context, the average of the scores of the participants obtained from the scales used standard deviation and Cronbach's Alpha values shown in Table 1. As seen in Table 1, the reliability of the scales used in the study shows that the Cronbach's alpha values are sufficient and the results obtained show that the scale and its sub-dimensions have sufficient reliability values. 
Table 1. Mean, Standard Deviation and Cronbach's Alpha Values of the Scales from the Sample

\begin{tabular}{lllll}
\hline Variables & N & Mean & S & Cronbach's Alpha \\
\hline Unrelenting standards & 379 & 8,83 & 3,53 &, 801 \\
Self-sacrifice & 379 & 15,79 & 5,62 &, 869 \\
Belittling Mother & 379 & 20,09 & 10,01 &, 944 \\
Anxious Mother & 379 & 19,22 & 7,53 &, 907 \\
Normative Mother & 379 & 38,05 & 16,54 &, 967 \\
Conditional Mother & 379 & 15,56 & 6,47 &, 909 \\
Belittling Father & 379 & 20,92 & 10,36 &, 943 \\
Anxious Father & 379 & 17,58 & 7,64 &, 918 \\
Normative Father & 379 & 38,18 & 16,51 &, 967 \\
Conditional Father & 379 & 15,46 & 6,58 &, 915 \\
Social Approval & 379 & 78,70 & 20,68 &, 944 \\
\hline
\end{tabular}

To determine the intensity and direction of the relationships among the variables included in the study, Pearson Product Moment Correlation Analysis performed, and the results of the analysis presented in Table 2. Various conditions must be provided to test the mediator variables. These conditions generally consist of the following steps (Baron, \& Kenny, 1986; Shrout, \& Bolger, 2002; Tingley, Yamamoto, Hirose, Keele, \& Imai, 2014):

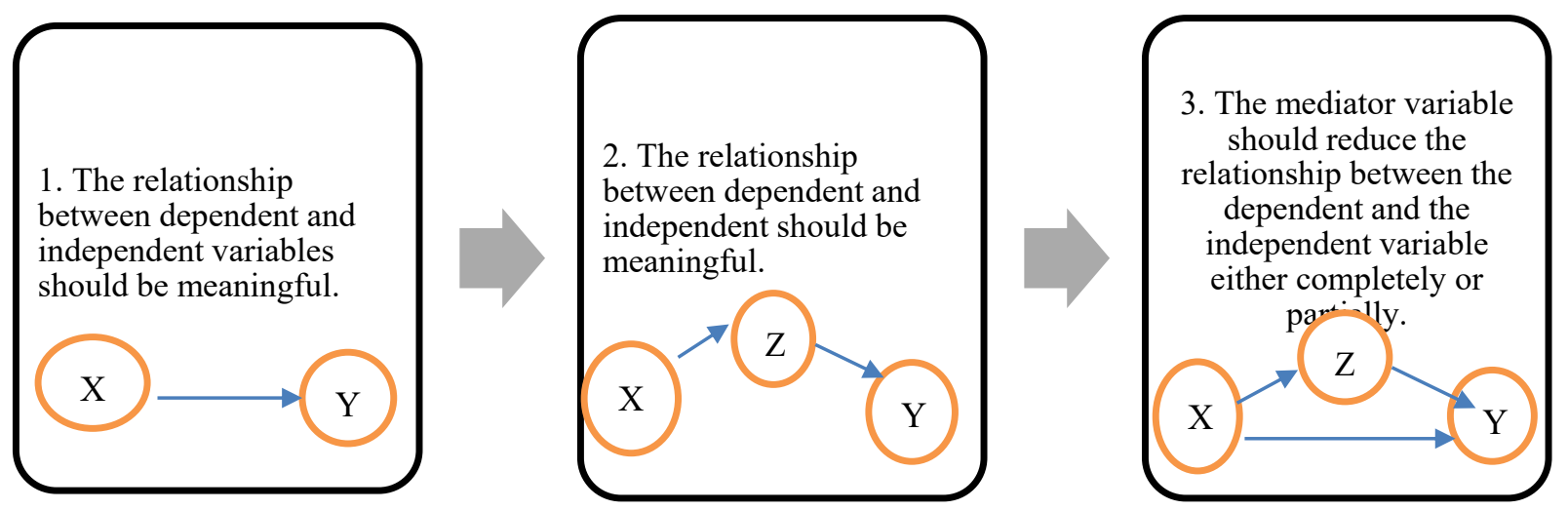

Figure 1. Conditions for Testing of Mediator Variables

Correlation values in Table 2 interpreted by taking into account the prerequisites.

Table 2. Mean, Standard Deviation, Correlation and Reliability Values of Study Variables

\begin{tabular}{|c|c|c|c|c|c|c|c|c|c|c|c|}
\hline Variables & 1 & 2 & 3 & 4 & 5 & 6 & 7 & 8 & 9 & 10 & 11 \\
\hline Unrelenting standards & 1 &, $107 *$ &, 068 &, 056 &, $69 * *$ &, $618 * *$ &, $110^{*}$ &, 069 &, $681 * *$ &, $612 * *$ &, $667 * *$ \\
\hline Self-sacrifice &, $107 *$ & 1 &, $589 * *$ &, $725 * *$ &,- 055 &,- 004 &, $607 * *$ &, $598 * *$ & ,006 &, 030 & ,090 \\
\hline Anxious Mother &, 056 &, $725 * *$ &, $751 * *$ & 1 &, 033 &, $101 *$ &, $746^{* *}$ &, $801 * *$ &, 081 &, $103 *$ &, $105^{*}$ \\
\hline Normative Mother &, $699 * *$ &,- 055 &, $180 * *$ & ,033 & 1 &, $856 * *$ &, $166^{* *}$ &, $108 *$ &, $913 * *$ &, $810 * *$ &, $755^{* *}$ \\
\hline Conditional Mother &, $618 * *$ &,- 004 &, $167 * *$ &, $101 *$ &, $856^{* *}$ & 1 &, $155^{* *}$ & ,089 &, $823 * *$ &, $899 * *$ &, $700 * *$ \\
\hline Belittling Father &, $110^{*}$ &, $607 * *$ &, $861 * *$ &, $746^{* *}$ &, $166^{* *}$ &, $155^{* *}$ & 1 &, $680 * *$ &, $237 * *$ &, $170 * *$ &, $148 * *$ \\
\hline Anxious Father & ,069 &, $598 * *$ &, $751 * *$ &, $801 * *$ &, $108^{*}$ & ,089 &, $680 * *$ & 1 &, $149 *$ &, 079 &, 084 \\
\hline Normative Father &, $681 * *$ &, 006 &, $192 * *$ &, 081 &, $913 * *$ &, $823 * *$ &, $237 * *$ &, $149 * *$ & 1 &, $855^{* *}$ &, $766^{* *}$ \\
\hline Conditional Father &, $612 * *$ &, 030 &, $150 * *$ &, $103 *$ &, $810 * *$ &, $899 * *$ &, $170 * *$ &, 079 &, $855^{* *}$ & 1 &, $706 * *$ \\
\hline Social Approval &, $667 * *$ &, 090 &, $122 *$ &, $105^{*}$ &, $755 * *$ &, $700 * *$ &, $148 * *$ &, 084 &, $766^{* *}$ &, $706 * *$ & 1 \\
\hline
\end{tabular}

$* \mathrm{p}<$ significant at level, 05

$* * \mathrm{p}<$ significant at level ,001 
Correlation values must be appropriate in order to be able to analyze the mediator role of self-sacrifice and high standards schemas in the relationship between the parenting types and need for social approval. When we look at the relationship between the variables of parenting styles and the need for social approval, it is seen in the table that all other variables are in a meaningful relationship except the protective father variable. Looking at the relationship between high standard and self-sacrifice schemas and need of social approval, which are considered as mediator variable, it was observed that the self-sacrifice schema was not in a significant relationship $(r=.90 ; p>.05)$. Therefore, the model will continue in the next process by including the mediator role effect of the model high standards schema. However, one of the most remarkable points in the correlation table; self-sacrifice schema with belittling mother-belittling father and the protective mother-protective father is in a high relationship with the parenting sub-dimensions. The same high correlation values can also be observed among the normative mother-father and conditional mother-father variables. The model was tested separately for both mother and father and the results are presented in model 1 and model 2.

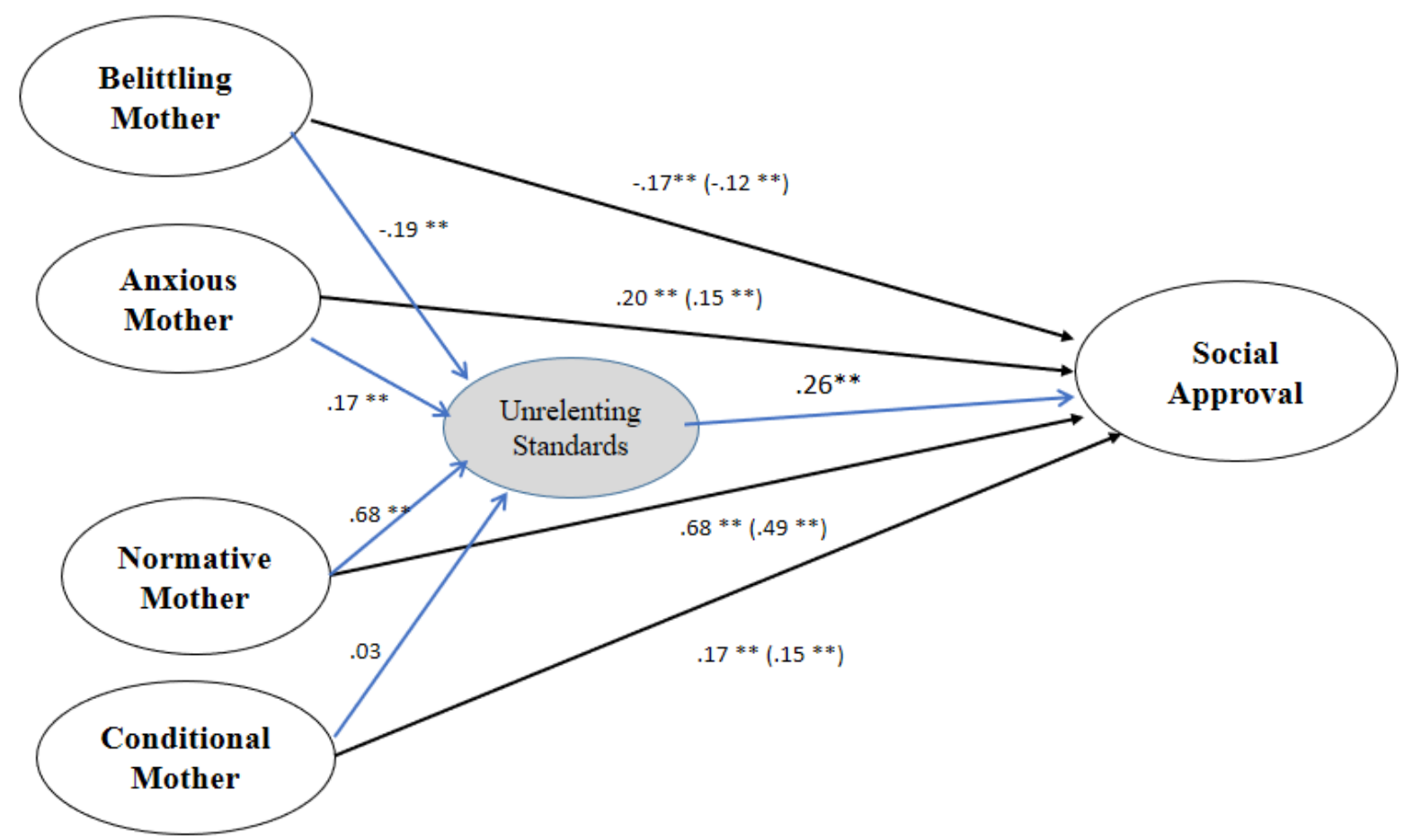

Model 1. Mediation Effect of High Standard Variation in the Relationship Between Mother Parenting Styles and the Need for Social Approval $(* * \mathrm{p}<.01)$

In Model 1, which is composed of the variables that mother parenting styles, high standards and need for social approval, are tested, the relations between mother parenting styles and the need for social approval were found to be statistically significant. When the ratio of the chi-square value to the degree of freedom $((\chi 2 / \mathrm{sd}=1,71)$ is below 3 , it indicates a good fit. When the goodness of fit indexes of the structural model are examined, it is seen that RMSEA $=.056 \mathrm{GFI}=.991 \mathrm{AGFI}=.906$ and $\mathrm{CFI}=.993$. These values show that the established structural model is in a good fit. All these analyses show that the high standards schema has a mediating role in this relationship. 


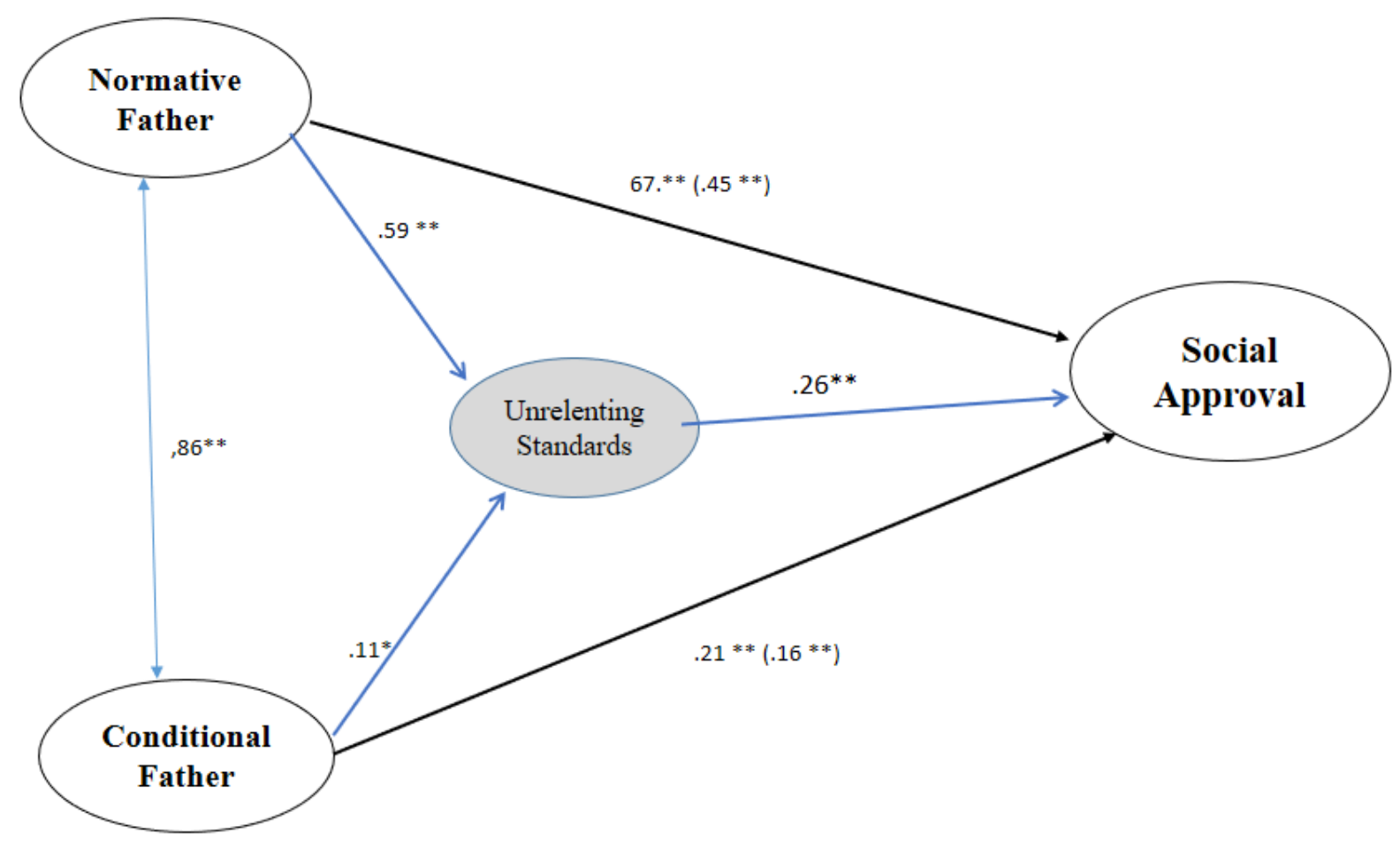

Model 2. Mediation Effect of High Standard Variation in the Relationship Between Father Parenting Styles and the Need for Social Approval $(* * \mathrm{p}<.01)$

When the model, which is composed of the normative-protective father parenting styles, high standards and need for social approval model, is tested in the model 2, the relations between the normative -conditional father parenting styles and the need for social approval were found to be statistically significant. When the ratio of the chi-square value to the degree of freedom $(\chi 2 / \mathrm{sd}=, 01)$ is below 3 , it indicates a good fit. When the goodness of fit indexes of the structural model are examined, it is seen that RMSEA $=.006$, GFI $=.999$, AGFI $=.988$ and CFI $=.999$. These values show that the established structural model is in a good fit. All these analyses show that the high standards scheme has a mediating role in this relationship.

When Table 2 which shows the results of the bootstrapping process is examined, it is seen that the total values of both the direct and indirect measured coefficients were significant in both models (bootstrap coefficient model 1 $=.285,95 \%$ G.A. $=-.107, .339$; bootstrap coefficient model $2=.193,95 \%$ G. A. $=.098, .304$ ). These results serve as a partial mediator between the high standards schema and the parenting styles of university students and their need for social approval. 
Table 3. Bootstrapping Process for the Model

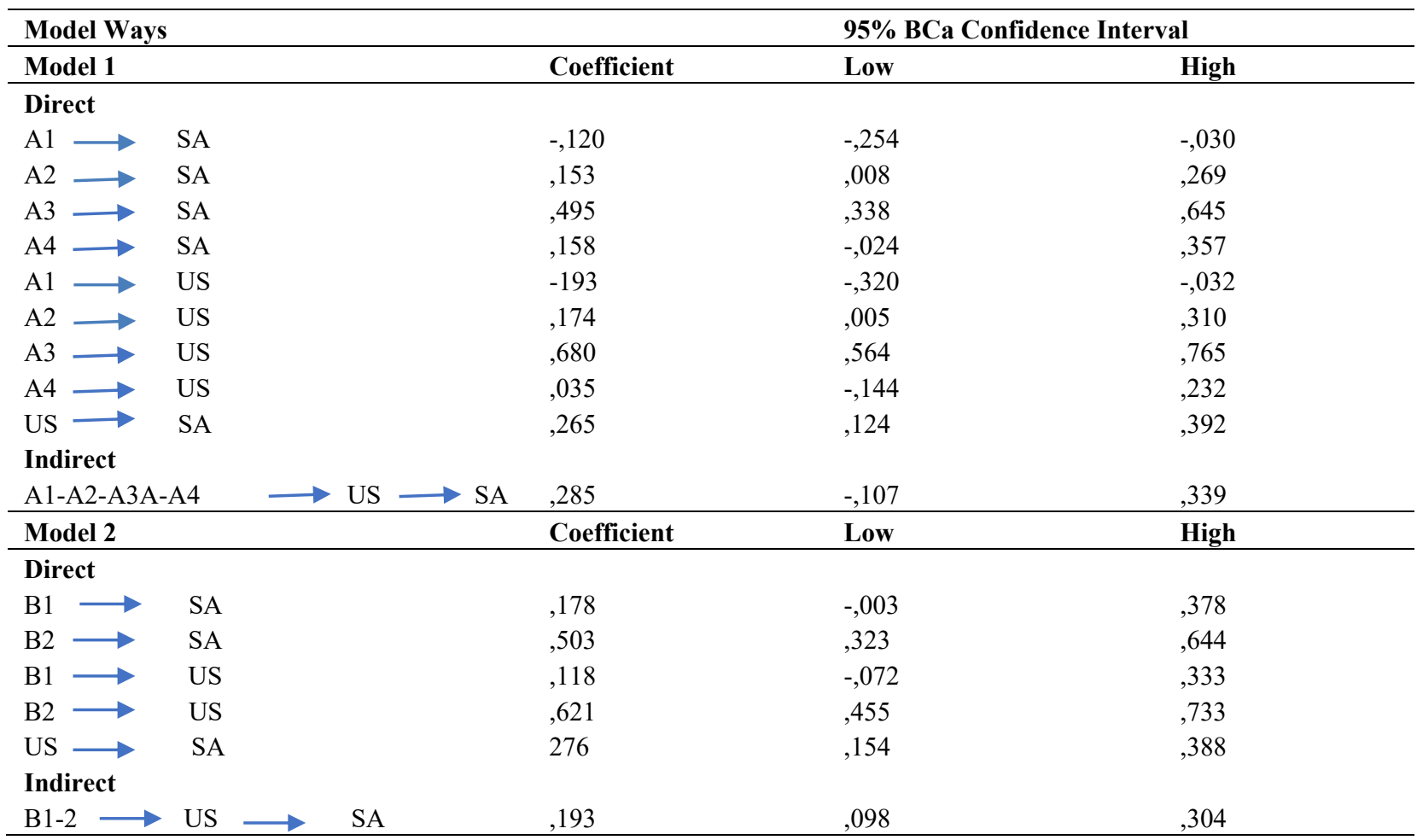

Note: $A 1$ Belittling Mother; $A 2$ Anxious Mother; $A 3$ Normative Mother; $A 4$ Conditional Mother; B1 Conditional Father; $B 2$ Normative Father; $S A$ Social Approval; US Unrelenting Standards

\section{Discussion}

In this research, the mediating role of self-sacrifice and high standards schemas in the relationship between normative, belittling/criticizing, overprotective/anxious, conditional/achievement-focused parenting styles and need for social approval examined. The effect of parenting styles that the individual perceives on specific schemas is known (Harris \& Curtin, 2002; Kapçı \& Hamamc1, 2010; Soygüt \& Çakır, 2009; Terri, Messman-Moore, \& Coates, 2007; Yurtsever \& Sütçü, 2017). In this study, it found that conditional / achievement-focused and normative parenting styles predicted high standards and self-sacrifice schemas. People who exposed to conditional / achievement-focused parenting styles always think about what others think of themselves. People with a self-sacrifice schema that are in a position to prioritize the needs of others and postpone their own needs are the people who want to meet the needs of others and come to a right place in their eyes. Again, as the families of the individuals who are grown conditional/achievement-focused expect the best from their children, it leads them to have high standard schemas that include perfectionism features such as not being satisfied with what they have and continue having new goals(Young, Klosko and Weishaar, 2017). Similar results observed in the literature. Çolakoğlu (2012), in his study, found that the attitudes of conditional father and normative mothers predict the self-sacrifice schema. Thus shows that the sacrifice schema increases as the exposure to conditional / achievement-focused, and normative attitudes increases. In his study of Ablard and Parker (1997), children exposed to conditional / achievement-focused parental attitudes have shown that they show signs of non-functional perfectionism, which is characteristic of the high standards schema.

However, no relation found between belittling/criticizing and overprotective parenting styles and high standards and the self-sacrifice schemas and need for social approval. These parenting styles appear to have no predictive power for the need for social approval and schemas. According to the literature, Sheffield (2005) found that belittling/criticizing parental attitudes were associated with an impaired autonomy schema domain that accommodated the high standards scheme that led to the need for social approval. According to Arslan's (2017) study, the belittling/criticizing parenting concept predicts the other-directedness and suppression domains predicting social adoption. When we look at the reviews on over-protective parenting attitudes, studies are suggesting that this attitude leads to shyness, obstacles to take responsibility, and need approval for this. (Erol and Avc1-Temizer, 2015; 
Pekşen-Akça, 2012; Turner, Rose, and Cooper, 2005). It has seen that the results of the study are different from the literature. Therefore, it thought that it could reevaluate with different tools of measurement and a separate sample group.

Another result of the research is that the conditional/achievement-focused and normative parental styles directly predicts both the need for social approval and indirectly predicts the high standards schema mediator variable. In other words, the demand for social approval of people exposed to normative and conditional parents is increasing. The high standards schema also leads to an increase in the social approval needs of people who exposed to normative and conditional parents. There is a need for approval to achieve perfection in the over vigilance and inhibition schema that already contains the high standards scheme (Young, Klosko, and Weishaar, 2017). As previously stated, people who exposed to conditional / achievement-focused parenting styles take serious action to meet and satisfy the parents' expectations. Because when they achieve high success, they get love and interest. For the continuity of passion and enthusiasm, people feel sufficient and self-confident in line with the expectations they meet. Thus only occurs when they are approved. They think that they are valuable as they get approval (Kolat, 2007; Akt \& Tortamış, 2014; Young, Klosko, and Weishaar, 2017). In this study, it has seen that the conditional parenting style leads to the need for social approval. Çolakoğlu (2012) also found in his research that conditional/achievement-focused parental styles predicted social approval. People who are exposed to the normative behavior of their parents highly need support, too. Individuals in need of approval are those who are afraid of being evaluated negatively.

Children who are convinced by their families in a normative way that they should always seem good try not to receive a severe criticism of their adulthood and to receive continuous approval. (Takako, 1994; Akt., Erkan, Güçray and Çam, 2002). In this study, it has seen that the normative parenting style leads to the need for social approval. Similar results also included in the literature. Erkan, Güçray, and Çam (2002), in their study, it revealed that people who exposed to the normative, strict attitude of the parents have a fear of being evaluated negatively. Likewise, according to the study of Sümer, Aktürk, and Helvaci (2010), the normative parenting attitude constitutes a significant concern that includes the need for approval. Eldoğan and Tunçel (2007) also found the normative mother as one of the parenting opinions that people with high levels of anxiety and need for approval in their studies.

The research is thought to be important in a few ways. Firstly, it is to reveal the differentiation of the high standards schema according to the mediator role in predicting the need for social approval of individual parenting styles. Another critical point is that it is one of the first studies to examine the interrelated relationship between normative, belittling/criticizing overprotective/anxious, conditional / achievement-focused parenting styles, high standards, and self-sacrifice schemas and the need for social approval. The other one is, while general parenting styles and general early incompatible schemas examined with different variables in the literature, in this study, individual parenting styles and the certain early period maladaptive schemas have used. Thus gives us more detailed information than general results. The fact that normative, conditional/achievement-focused parenting styles predict the need for social approval through the high standards scheme shows that parent-child relationship communication and events should also be taken into consideration while evaluating the need for social approval both during psychological counseling and in theoretically.

The fact that the research conducted on university students is one of the limitations of the research. Further investigations may be required to perform in the clinical sample group. Another limitation is that it remains limited to 4 different parenting styles and two different early schemas. A separate evaluation of other parenting styles and other schemas will give more detailed results.

\section{Limitations}

We would like to state that this study has some limitations. Since it is not possible to work with all scheme areas, certain scheme areas are preferred. Therefore, researchers can make studies by considering other schema areas. For this study, data were collected from a number of universities. The research can be designed by collecting data from groups with more students.

\section{References}

Ablard, K. E., \& Parker, W. D. (1997). Parents' achievement goals and perfectionism in their academically talented children. Journal of Youth and Adolescence, 26(6), 651-667. https://doi.org/10.1023/A:1022392524554

Arslan, R. (2017). Algılanan ebeveynlik biçimleri, erken dönem uyumsuz şemalar ve kişiler arası bağımlılık eğilimi arasindaki ilişsiler: Şema terapi modeli çerçevesinde bir inceleme. (Master's thesis, Hacettepe University, 
Ankara).

Azar, S. T., Nix, R. L., \& Makin-Byrd, K. N. (2005). Parenting schemas and the process of change. Journal of Marital and Family Therapy, 31(1), 45-58. https://doi.org/10.1111/j.1752-0606.2005.tb01542.x

Baron, R. M., \& Kenny, D. A. (1986). The moderator-mediator variable distinction in social psychological research: Conceptual, strategic, and statistical considerations. Journal of Personality and Social Psychology, 5, 1173-1182. https://doi.org/10.1037/0022-3514.51.6.1173

Beck, A.T. (2008). Bilişsel Terapi ve Duygusal Bozuklukları. İstanbul: Litera.

Burns, D. (2016). Iyi hissetmek yeni duygudurum tedavisi. In H. A. Karaosmanoğlu (Çev. Ed.), (E. Tuncer, Ö. Mestçioğlu, İ. Erdem Atak ve G. Acar, Çev.). İstanbul: Psikonet.

Çağdaş, A., \& Seçer, Z. (2004). Anne Baba Eğitimi. Konya: Eğitim.

Ceylan, H. (2011). Üniversite ögrencilerinin sosyal kaygı düzeylerinin yordanması (Master's thesis). Ege University, İzmir).

Çolakoğlu, E. T. (2012). Genç yetişkinlerde kendilik algısı, erken dönem uyumsuz şemalar, algılanan ebeveynlik stilleri ve kişilerarası ilişkiler. (Master's thesis, Maltepe University, İstanbul).

Cox, S. L., \& Chen, J. (2015). Perfectionism: A contributor to social anxiety and its cognitive processes. Australian Journal of Psychology, 67(4), 231-240. https://doi.org/10.1111/ajpy.12079

Cullum, J. L. (2009). Maladaptive schemas as a predictor of residential treatment outcomes in females with eating disorders. (Doctoral dissertation, Utah State University). Retrieved from https://digitalcommons.usu.edu/etd/459

Demir, M., \& Kaya, F. (2016). Obsesif kompulsif bozukluk ile ilişkilerle ilgili bilişsel çarpıtmalar arasındaki ilişkinin yapısal eşitlik modeli ile incelenmesi. Atatürk Üniversitesi Edebiyat Fakültesi Dergisi, 57, $175-186$.

Dökmen, Ü. (1996). İletişim Çalışmaları ve Empati. İstanbul: Sistem.

Eldoğan, D., \& Tunçel, E. (2017). Kırılgan narsisizm ve sosyal kaygı bozukluğu: Benzerlikler ve farklılıklar. Nesne Psikoloji Dergisi, 5(11), 426-448. https://doi.org/10.7816/nesne-05-11-05

Erkan, Z. (2002). Sosyal kaygı düzeyi yüksek ve düşük ergenlerin ana baba tutumlarına ilişkin nitel bir çalışma. Çukurova Üniversitesi Sosyal Bilimler Enstitüsü Dergisi, 10(10).

Erkan, Z., Güçray, S., \& Çam, S. (2002). Ergenlerin sosyal kaygı düzeylerinin ana baba tutumları ve cinsiyet açısından incelenmesi. Çukurova Üniversitesi Sosyal Bilimler Enstitüsü Dergisi, 10(10), 64-75.

Erol, M., \& Temizer, D. A. (2015). Ergenlerin utangaçlık düzeylerinin incelenmesi. Türk Psikolojik Danışma ve Rehberlik Dergisi, 5(44).

Erözkan, A. (2004). Romantik ilişkilerde reddedilmeye dayalı incinebilirlik, bilişsel değerlendirme ve başaçıkma (Doctoral dissertation, Karadeniz Teknik Üniversitesi, Trabzon).

Erözkan, A. (2007). Üniversite öğrencilerinin reddedilme duyarlıkları ile sosyal kaygı düzeylerinin bazı değişkenlere göre incelenmesi. Selçuk Üniversitesi Sosyal Bilimler Enstitüsü Dergisi, 1(17), 225-240.

Erözkan, A. (2012). Examination of relationship between anxiety sensitivity and parenting styles in adolescents. Educational Sciences: Theory and Practice, 12(1), 52-57.

Harris, A. E., \& Curtin, L. (2002). Parental perceptions, early maladaptive schemas, and depressive symptoms in young adults. Cognitive Therapy and Research, 26(3), 405-416. https://doi.org/10.1023/A:1016085112981

Jansson-Fröjmark, M., \& Linton, S. J. (2007). Is perfectionism related to pre-existing and future insomnia? A prospective study. British journal of clinical psychology, 46(1), 119-124. https://doi.org/10.1348/014466506X158824

Kapçı, E. G., \& Hamamcı, Z. (2010). Aile işlevi ile psikolojik belirtiler arasındaki ilişki: Erken dönem uyum bozucu şemaların aracı rolü. Klinik Psikiyatri, 13(3), 127-136.

Karakaş, Y. (2008). Lise öğrencilerinin mükemmeliyetçilik düzeyleri ile sosyal kaygı düzeyleri arasındaki ilişki. (Master's thesis). Muğla University, Muğla).

Karaşar, B. (2014). Üniversite öğrencilerinde sosyal onay ihtiyacının çeşitli değişkenler açısından incelenmesi. (Doctoral Dissertation). Ankara University. 
Kömürcü, B., \& Soygüt-Pekak, G. (2017). Erken Dönem Uyumsuz Şemalar, Ebeveynlik Biçimleri ve Psikolojik Belirtiler İle Psikolojik Dışlanmanın Tehdit Ettiği İhtiyaçlar Arasındaki İlişkiler. Klinik Psikiyatri, 20, 6-18.

Leite, W. L., \& Beretvas, S. N. (2005). Validation of scores on the marlowe-crowne social desirability scale and the balanced inventory of desirable responding. Educational and Psychological Measurement, 65, 140-154. https://doi.org/10.1177/0013164404267285

McCarthy, M. C., \& Lumley, M. N. (2012). Sources of emotional maltreatment and the differential development of unconditional and conditional schemas. Cognitive Behaviour Therapy, 41(4), 288-297. https://doi.org/10.1080/16506073.2012.676669

McGinn, L. K., Cukor, D., \& Sanderson, W. C. (2005). The relationship between parenting style, cognitive style, and anxiety and depression: Does increased early adversity influence symptom severity through the mediating role of cognitive style. Cognitive Therapy and Research, 29(2), 219-242. https://doi.org/10.1007/s10608-005-3166-1

Murris P. (2006). Maladaptive schemas in non-clinical adolescents: relation to perceived parental rearing parental rearing behaviours, big five personality factors and psychological symptoms. Clin Psychol Psychother, 13, 405-413. https://doi.org/10.1002/cpp.506

Pekşen-Akça, R. (2017). Ana-babaların çocuk yetiştirmede aşırı koruyucu olmaları. Akademik Bakış Uluslararası Hakemli Sosyal Bilimler e-Dergisi, 29, 1-12.

Roelofs, J., Lee, C., Ruijten, T., \& Lobbestael, J. (2011). The mediating role of early maladaptive schemas in the relation between quality of attachment relationships and symptoms of depression in adolescents. Behavioural and Cognitive Psychotherapy, 39(4), 471-479. https://doi.org/10.1017/S1352465811000117

Sarıtaş, D., \& Gençöz, T. (2013). Anne ret algısı ile psikolojik sorunlar arasındaki ilişkide erken dönem uyumsuz şemaların aracı rolü. Türk Psikiyatri Dergisi, 24(1), 40-47.

Scott, J. H., Yap, K., Francis, A. J., \& Schuster, S. (2014). Perfectionism and its relationship with anticipatory processing in social anxiety. Australian Journal of Psychology, 66(3), 187-196. https://doi.org/10.1111/ajpy.12045

Sertelin Mercan, Ç., \& Yavuzer, H. (2017). Bilişsel-Davranışçı yaklaşımla bütünleştirilmiş sosyal beceri eğitiminin ergenlerin sosyal kayg1 düzeyine etkisi. Elektronik Sosyal Bilimler Dergisi, 16(63), 1187-1202. https://doi.org/10.17755/esosder.291364

Sheffiled, A., Waller, G., Emanuelli, F., Murray, J., \& Meyer, C. (2005). Links between parenting and core beliefs: preliminary psychometric validation of the Young parenting inventory. Cognitive Theory and Research, 29(6), 787-802. https://doi.org/10.1007/s10608-005-4291-6

Sherry, B. A. (2002). Perfectionism dimensions, perfectionistic dysfunctional attitudes, need for approval, and depression symptomps in adult psychiatric patients and young adults. (Master's thesis, The University Of British Columbia). Retrieved from https://circle.ubc.ca/bitstream/handle/2429/13433/ubc_20020559.pdf?sequence=1

Shrout, P. E., \& Bolger, N. (2002). Mediation in experimental and nonexperimental studies: new procedures and recommendations. Psychological Methods, 7, 422-445. https://doi.org/10.1037/1082-989X.7.4.422

Soygüt G., \& Çakır Z. (2009). Ebeveynlik biçimleri ile psikolojik belirtiler arasindaki ilişkilerde kişilerarasi şemalarin araci rolü: Şema odakli bir bakiş. Türk Psikiyatri Dergisi, 20, 144-152.

Soygüt G, Çakır Z, Karaosmanoğlu A (2008). Ebeveynlik biçimlerinin değerlendirilmesi: Young Ebeveynlik Ölçeğinin psikometrik özelliklerine ilişkin bir değerlendirme. Türk Psikoloji Dergisi 11, 17-30.

Sübaşı, G. (2010). Üniversite öğrencilerinde sosyal kaygıyı yordayıcı bazı değişkenler. Eğitim ve Bilim, 32(144), 3-15.

Sümer, N., Gündoğdu Aktürk, E., \& Helvacı, E. (2010). Anne-baba tutum ve davranışlarının psikolojik etkileri: Türkiye'de yapılan çalışmalara toplu bakış. Türk Psikoloji Yazıları, 13(25), 42-59.

Tabachnick, B. G., \& Fidell, L. S. (2015). Çok değiş̧kenli istatistiklerin kullanımı (Çev. Ed. M. Baloğulu). Anakar: Nobel.

Terri L., Messman-Moore T. L., \& Coates A. A. (2007). The impact of childhood psychological abuse on adult interpersonal conflict. Journal of Emotional Abuse, 7(2), 75-92. https://doi.org/10.1300/J135v07n02 05

Thimm, J. C. (2010). Mediation of early maladaptive schemas between perceptions of parental rearing style and 
personality disorder symptoms. Journal of Behavior Therapy and Experimental Psychiatry, 41(1), 52-59. https://doi.org/10.1016/j.jbtep.2009.10.001

Thomas, A. R. (2000). Social anxiety disorder. Journal of Clinical Psychiatry, 59, 27-31.

Tingley, D., Yamamoto, T., Hirose, K., Keele, L., \& Imai, K. (2014). Mediation: R package for causal mediation analysis. Journal of Statistical Software, 59(5), 1-38. https://doi.org/10.18637/jss.v059.i05

Tortamış, M. (2014). Evli Bireylerde Romantik Kıskançlık Türü ve Aldatma Eğiliminin Şema Terapi Modeli Çerçevesinde Değerlendirilmesi (Master's thesis). Hacettepe University, Ankara.

Türk, F., Duy, B., Hamamc1, Z., \& Altınok, A. (2017). The Mediating Role of Irrational Beliefs between Parenting Style, Interpersonal Style and Conflict Tendency. International Online Journal of Educational Sciences, 9(2), 420-438. https://doi.org/10.15345/iojes.2017.02.010

Turner, H. M., Rose, K. S., \& Cooper, M. J. (2005b). Schema and parental bonding in overweight and nonoverweight female adolescents. International Journalof Obesity, 29(4), 381-387. https://doi.org/10.1038/sj.ijo.0802915

Twenge, J. M., \& Im, C. (2007). Changes in the need for social approval, 1958- 2001. Journal of Research Inpersonality, 41, 171-189. https://doi.org/10.1016/j.jrp.2006.03.006

Yavuzer, H. (2005). Ana-baba ve Çocuk. İstanbul: Remzi.

Young, J. E., Klosko, J. S., \& Weishaar, M.E. (2017). Şema Terapi. İstanbul: Litera.

Yurtsever, S. S., \& Sütcü, S. T. (2017). Algılanan Ebeveynlik Biçimleri ile Bozulmuş Yeme Tutumu Arasındaki İlişkide Erken Dönem Uyumsuz Şemaların ve Duygu Düzenleme Güçlüğünün Aracı Rolü. Türk Psikoloji Dergisi, 32(80), 20-43.

Zeigler-Hill, V., Green, B. A., Arnau, R. C., Sisemore, T. B., \& Myers, E. M. (2011). Trouble ahead, trouble behind: Narcissism and early maladaptive schemas. Journal of Behavior Therapy and Experimental Psychiatry, 42(1), 96-103. https://doi.org/10.1016/j.jbtep.2010.07.004

\section{Copyrights}

Copyright for this article is retained by the author(s), with first publication rights granted to the journal.

This is an open-access article distributed under the terms and conditions of the Creative Commons Attribution license (http://creativecommons.org/licenses/by/4.0/). 